\title{
Erosi Nilai Agama dalam Masyarakat
}

\author{
Oleh M Rusli Karim
}

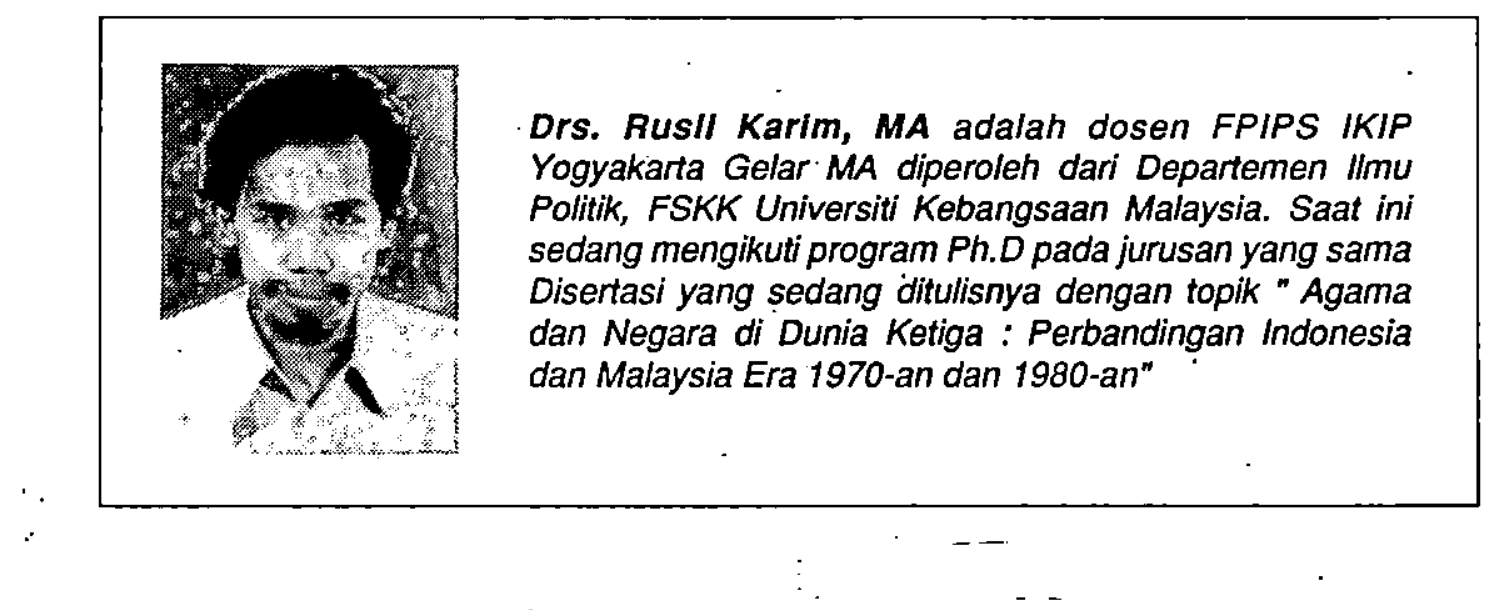

Robert $\mathrm{N}$. Bellah di dalam uraiannya tentang agama modem dengan begitu yakin memberikan satu gambaran yang jelas tentang kedudukan agama di tengah-tengah arus transformasi masyarakat. Secara lebih khusus Bellah memaparkan pengalaman masyarakat Barat memasuki era modern, terutama letak dan daya tanggap agama terhadapnya. Yang menarik adalah bahwa pada awal era modem ini dengan tekanan yang keras dari agama, berkembanglah satu konsep sistem sosial dalam bentuk masyarakat demokratik. Pada saat yang sama kelenturan sosial mengalami perimbangan guna menentang kekakuan doktrinal (ortodoksi Protestan) dan kekakuan karakterologis (kepribadian Puritan).

Dalam batas tertentu, kekakuan ini diperlukan guna memungkinkan munculnya kelenturan di dalam sistem sosial, tetapi inilah ciri pokok fase modem yang lebih baru, dimana kebudayaan dan kepribadian itu sendiri harus dianggap sebagai sesuatu yang tidak berujung untuk dapat diperbarui. Hal ini ditandai dengan hancumya makna dan kegagalan standar-standar moral. Tidak diragukan banyak sekali kemungkinan distorsi patologis dalam situasi modem.

Sengaja penulis kutipkan pandangan Bellah di atas untuk menunjukkan salah satu kecenderungan transformasi yang dialami masyarakat dalam menuju tatanan masyarakat industrial. Masyarakat industri jelas merupakan satu produk peradaban Barat. Bagi masyarakat Barat sendiri, revolusi industri telah mengubah hampir segala segi kehidupan mereka. Bahkan sejak sékitar dua dekade yang Ialu mereka telah memasuki satu era baru, yang oleh Daniel Bell disebut sebagai masyarakat Pasca-Industri, yang komponennya mencakup sebelas aspek.

Pertama, pemusatan pengetahuan teoritis. Inovasi teknologi sangat membutuhkan basis pengetahuan teoritis dan sains material. Dari sini berkembanglah industri komputer, elektronik, optik, "polymers" dan lain-lain. Kedua, penciptaan satu teknologi intelektual baru. Dengan piranti ini, pembangunan ekonomi dan pengembangan teknik dapat dilaksanakan. Ketiga, perluasan satu kelas pengetahuan; yaitu kelas teknik dan profesional. Di tahun 1975, di Amerika Serikat, diantara delapan juta tenaga kerja, jika ditambah dengan manajer maka jumlah kelompok ini mencapai 25 persen atau dua juta orang. Keempat, perubahan dari barangbarang kepada jasa. Di negara Paman Sam tersebut pada tahun yang sama, sekitar 65 persen pekerja terlibat dalam industri jasa. Pada era Pasca-Industri jasa yang paling menonjol adalah di bidang kemanusiaan, profesional dan teknikal.

Kelima, perubahan dalam karakter kerja.Di dalam masyarakat pra-industri pekerjaan utama adalah permainan melawan alam; dalam masyarakat industri adalah permainan memanipulasi alam; sedangkan dalam era Pasca-Industri adalah permainan di antara masingmasing orang. Keenam, peran wanita. Pada masyarakat industri pekerjaan didominasi kaum pria, maka dalam era Pasca-Industri (PI) banyak peluang kerja untuk kaum ibu. Ketujuh, sains sebagai "imago". Kedelapan, "situs" sebagai unit politik. Kesembilan, meritokrasi. Kesepuluh, berakhimya kelangkaan. Kesebelas, ekonomi informasi. 
Di dalam masyarakat tersebut, menurut Drucker, faktor penentu produksi, sebagai kunci keberhasilan ekonomi, bukanlah kapital, lahan atau tenaga kerja melainkan ilmu pengetahuan. Kelas yang menentukan di dalam masyarakat adalah pekerja di bidang ilmu pengetahuan dan jasa.

Kendatipun masyarakat kita belum sampai ke tahap seperti dibayangkan di atas, tetapi kita tetap cemas terhadap kemungkinan timbulnya dampak negatif dari proses industrialisasi yang kita lalui.

Mengapa industrialisasi perlu diwaspadai? Menurut hemat penulis, ada beberapa alasan yang layak dikemukakan. Pertama, gejala industrialisasi adalah diimpor dari Barat yang dikembangkan melalui nilai, logika, norma dan tujuan yang belum tentu selaras dengan apa yang ada di dalam masyarakat kita. Karena itu, setiap proses adopsi haruslah didasarkan pada pertimbangan adaptasi. Dengan cara ini pengaruh negatif "bias." ke-Barat-baratan dapat dihindari.

Kedua, modemisasi dan pembangunan bangsa yang terlalu berorientasi kepada upaya mengejar pertumbuhan ekonomi besar kemungkinan tidak terlalu peduli terhadap aspek pembangunan yang tidak memiliki kaitan langsung dengan pembangunan ekonomi. Dalam hubungan ini, mungkin juga agama dipersepsikan tidak lebih dari sekedar pranata budaya yang bisa dipolitisasikan untuk kepentingan pragmatis tertentu. Ini berarti bahwa agama hanya menempati posisi sebagai "instrumen pelengkap". Pembangunan keagamaan tidaklah menempati kedudukan sentral. Inilah tatanan masyarakat sekular.

Ketiga, dinamika masyarakat tidak hanya ditentukan oleh masyarakat sendiri melainkan oleh para perumus perencanaan pembangunan. Dalam hal ini, pemerintahlah yang menentukan "cetak biru" pembangunan, bahkan peranan pemerintah sangat dominan. Dengan demikian, rakyat lebih dipandang sebagai "obyek" rekayasa pembangunan. Maka rakyat tidak memiliki kemandirian dalam berhadapan dengan pemerintah.

Tiga karakter di atas dengan jelas menunjukkan keberadaan agama dalam arus transformasi masyarakat. Sebagai bangsa yang dikenal berkepribadian keagaman, maka marginalisasi kedudukan dan peranan agama tersebut tentu akan menimbulkan konflik di dalam masyarakat. Inilah asumsi dasar keseluruhan analisis ini. Konflik seperti ini merupakan gejala universal yang menimpa hampir semua bangsa yang melakukan modernisasi. Yang menjadi masalah utama adalah bagaimana mencari bentuk sintesis kreatif pembangunan agar nilai-nilai tradisional-primordial masyarakat yang baik dapat bertahan hidup, bahkan saling mendukung dan berdampingan dengan modemitas yang melanda masyarakat, sehingga agama, misalnya, dapat betul-betul berfungsi sebagai ruh atau jiwa dalam segenap proses dan kegiatan pembangunan. Karena itu, para penulis tugas berat masyarakat kita dewasa ini adalah mengefektifkan realitas keberagamaan masyarakat.

Uraịan singkat ini akan memaparkan satu pandangan umum tentang erosi nilai-nilai agama di dalam masyarakat kita bersamàan dengan proses pembangunan dan modemisasi bangsa. Keseluruhän uraian ini tidak didasarkan atas penelitian empiris, melainkan lebih mengandalkan analisis spekulatif, yang memerlukan pembuktian melalui penelitian mendalam di masa depan.

\section{Refleksi pengalaman agama}

Sesuai dengan ajaran Islam, Allah menurunkan agama ini adalah untuk mengatur kehidupan manusia dalam relasi tiga serangkai: Manusia, Allah dan alam semesta. Tujuannya yang paling umum adalah menjaga keharmonisan. Dalam hal ini, manusia adalah satusatunya hamba Allah yang memperoleh mandat paling berat, yaitu memakmurkan jagat raya ini dan menempatkan diri secara tepat dan benar di depan Allah, sesuai dengan hakekat penciptaannya.

Kualitas manusia di mata Allah sangat ditentukan oleh kedekatan atau kejauhannya dengan orbit Sang Maha Pencipta. Dalam hubungan ini, maka kehidupan dalam Islam tiada lain adalah arena untuk menguji .apakah manusia dapat menjaga keseimbangan harmonis di atas atau sebaliknya. Di dalam kenyataannya memang sejarah peradaban manusia tidak selalu ditandai oleh kisah sukses melulu dan kontinu, melainkan bersifat fluktuatif, jatuh-bangun. Ada kalanya bandul lonceng kemanusiaan mendekat kepada orbit Ketuhanan, sementara pada waktu berikutnya terjadi yang sebaliknya, dimana manusia menjadi makhluk Allah yang bandel, lupa diri, bahkan bersikap sombong terhadap Sang Penciptanya sekalipun. Inilah yang diceritakan secara panjang lebar di dalam Al-Qur'an Surat Al A'raf.

Sebelum Nabi Muhammad dibangkitkan, Allah selalu mengutus para nabi dan rasul-Nya yang basu begitu manusia makin menjauhkan diri dari ajaran agama-Nya. Misinya adalah untuk mengembalikan manusia ke jalan yang benar, sehingga hakekat hidup yang sesungguhnya dapat dicapai. Menurut konsepsi Islam, pada dasamya, ada tiga pertanda kehancuran peradaban manusia, pertama, manusia tidak percaya pada eksistensi Allah. Kedua, tidak percaya pada dirinya sendiri; dan ketiga, manusia melakukan kerusakan di muka bumi. 
Sekarang, coba kita tengok kembali peradaban manusia modem kontemporer. Menurut hemat penulis, kehidupan kita sekarang ini penuh ditandai oleh paradoks. Di satu segi, umat manusia, terutama jika ditilik dari ukuran kebendaan, telah meraih sukses yang luar biasa hebatnya. Berkat kemajuan Iptek, kehidupan manusia masa kini penuh dengan kenikmatan. Teknologi telah menciptakan berbagai kemudahan, yang memungkinkan manusia menjelajahi dan mengeksploitasi segenap ciptaan Allah. Sekat-sekat ruang, waktu dan tempat hampir-hampir dapat diatasi semuanya oleh manusia. Tetapi bersamaan dengan keberhasilan tersebut manusia modern makin menjauhkan diri dari orbit Ketuhanan, bahkan ada yang dengan begitu angkuhnyá telah menuhankan otaknya sendiri, seperti terungkap dalam ucapan "Thomas Paine, bahiwa "otak saya adalah gereja saya".

Ini menupakan satu pertanda dari kecenderungan negatif seperti yang diperingatkan di dalam agama kita seperti telah disinggung di atas. Yaitu manusia mengingkari Allah dan menuhankan dirinya sendiri. Begitu juga pertanda kehancuran ketiga, melakukan kerusakan, juga dapat kita jumpai di mana-mana di sekeliling kita. Contoh yang paling menggenaskan adalah munculnya patologi sosial seperti ketagihan narkotika, terlibat dalam lembah prostitusi, hubungan seks bebas yang diikuti. oleh munculnya virus HIV, yang menimbulkan penyakit AIDS; ada pula penyakit stress yang diakibatkan oleh keterasingan dan sikap hidup individualistis berlebihan dari masyarakat industri modem. Jadi, di satu segi, manusia kian rasional, tetapi di segi yang lain mereka menghancurkan diri sendiri dan masa depannya melalui tindakan-tindakan yang tidak rasional sama sekali.

Di negara kita, walaupun kepesatan kemajuan industri masih jauh berada di bawah negara-negara industri terkemuka tetapi akhir-akhir ini makin dirasakan bahwa akibat transformasi menuju masyarakat industri, juga telah muncul gejala-gejala negatif seperti sifat tamak terhadap harta, menggunakan segala cara untuk mencapai tujuan, persaingan tidak sehat, mengabaikan norma bersama, terjadi. manipulasi, kolusi, bahkan korupsi kian menjadi-jadi.

Dalam situasi seperti dipaparkan di atas, agama tinggal berfungsi sebagai "tameng" dan identitas simbolis-primordialistis, bukan lagi sebagai kriteria penentu tingkah laku dalam relasi bisnis, sosial, politik dan budaya. Manusia hanya beragama dalam lingkungan dan konteks tertentu yang sangat terbatas; sementara totalitas kehidupan telah diputuskan sama sekali keterkaitannya dengan agama.
Lalu, pada dimensi keberagamaan yang manakah afiliasi keagamaan itu masih dapat ditemukan dalam relung kehidupan kita? Penulis tidak bermaksud menjawab pertanyaan ini. Namun, perhatikan tujuh dimensi keberagamaan seperti yang dikemukakan Ninian Smart berikut ini: dimensi ritual atau praktikal, dimensi etis/legal, dimensi pengalaman dan emosional, dimensi normatif atau mitis, dimensi doktrinal atau filosofis, dimensi kelembagaan dan keorganisasian, dan dimensi material dan artistik. Menurut hemat penulis, paling tidak di dalam masyarakat kita telah kehilangan dimensi etis atau legal, dañ dimensi doktrinal. Di dalam masyarakat kita kadar kedua dimensi tersebut tampak makin menurun. Etika dan kehidupan kita masih bersendikan keagamaan, tetapi di dalam kenyataannya sumber etika dan aturan hidup kita semakin menjauh dari Islam. Dengan demikian, jangan diharapkan akan muncul komunitas muslim dalam masyarakat seperti yang dipaparkan di atas.

Kembali meminjam pendapat para pakar sosiologi, Durkheim telah mengingatkan kita, bahwa penganekaragaman struktural dalam masyarakat industri telah menghasilkan "atominasi", identitas yang terpecah, impersonalitas, dan birokratisasi. Yang terjadi di dalam masyarakat semacam ini adalah proses yang makin menjauhkan kita dari nilai-nilai keagamaan dan dari hubungan komunal di antara umat seagama.

Dua pakar lainnya, Apter dan Andrain, menyatakan bahwa di dalam masyarakat timbul gerakan protes untuk menentang kecenderungan di atas melalui gerakan "sakralisasi", menentang cara pandang duniawiyah yang mengutamakan rasionalitas teknik instrumental dan dunia toleransi pluralitas yang profan. Sebaliknya, mereka memegang teguh nilai-nilai transendental ekspresif, tujuan tertinggi yang bersifat mitis, identitas bersama yang bersifat totalitas, ikatan pribadi yang intim, dan spontanitas komunal.

Kenyataan ini bisa dilihat dari perlawanan yang dilakukan penganut agama di negara terjajah. Selama era penjajahan agama merupakan sumber motivasi menentang pemerintah kolonial, dominasi kelompok etnis, tekanan budaya dan modemisasi sekular.

Di negara kita, pada awal abad ke-20 agamalah yang menjadi sumber utama motivasi pergerakan dan revolusi melawan penjajah. Di Afrika, menurut Mbiti, agama berfungsi melalui tiga tingkatan pengaruh, yaitu pertama, "contact religion", di mana seseorang tidak merasakan adanya kontradiksi dalam menganut keyakinan yang campur-aduk; kedua, "instant-religion", gejala ini timbul ketika manusia dalam menghadapi kesulitan; ketiga "transfused-religion", agama menjadi 
lambang pemersatu masyarakat, tanpa kedalaman teologis, komitmen dan personal.

Memang, banyak corak keberagamaan yang kian mencemaskan. Salah seorang pakar bimbingan dan penyuluhan, Genia, mendasarkan pendapatnya atas penelitian empiris di Barat menunjukkan bagaimana kecenderungan beragama di kalangan anak muda di sana seperti berikut:

1. Keyakinan egosentris, ini dialami oleh orang yang kurang memiliki kekuatan ego, integrasi emosional dan kepercayaan dasar yang diperlukan demi terjadinya hubungan yang stabil, dewasa.

2. Keyakinan dogmatis, untuk mencari kecintaan dan pengakuan dari Tuhan.

3. Keyakinan transisional, terjadi pada seseorang yang mengalami kegoncangan spiritual, suka mempertanyakan dan penuh keraguan.

4. Keyakinan intemalisasi yang diciptakan kembali, yaitu bagi mereka yang terikat pada keyakinan yang dipilih sendiri, karena dipandang memberi makna, tujuan dan pemenuhan spiritual.

5. Keyakinan transenden, seseorang yang mampu mencapai tingkat evolusi spiritual.

Di dalam realitas kehidupan sehari-hari masyarakat kita, tampaknya tidak sedikit diantara umat Islam yang baru mencapai intensitas yang beragam. Kontradiksi budaya juga tidak dapat kita hindari. Di satu pihak masyarakat kian didorong untuk makin materialistis, individualistik dan hedonistis, bahkan sekularistis, tetapi pada segi yang lain, kampanye fungsionalisasi agama digalakkan secara struktural. Maka sebagai kelanjutannya, kehidupan kita secara sistematik kian diperkaya oleh gejala-gejala serba paradoksial, misalnya bersamaan dengan kian maraknya pengajian agama, berdirinya sarana-sarana ibadah, makin banyaknya jumlah yang melakukan ibadah haji, secara sistematis diciptakan pula peluang-peluang untuk terjadinya kemaksiatan. Karena itu, jangan heran jika korupsi makin meningkat kualitas dan kuantitasnya justru pada saat meningkatnya kampanye penghayatan agama, sehingga bangsa Indonesia yang dikenal sebagai berpenduduk Islam terbesar di dunia adalah juga bangsa yang dilanda oleh korupsi yang terbesar di dunia pula, yakni sebanding dengan posisi jumlah penduduknya, nomor empat besar.

Mengapa hal ini bisa terjadi? Paling tidak, beberapa penyebab berikut dapat kita fikirkan bersama.

Pertama, dominannya pengaruh modemisasi yang dilandasi oleh tuntutan mengejar pertumbuhan ekonomi sebagai basis pembentukan masyarakat industri. Inilah satu-satunya ukuran absolut kemajuan. Dan ini pulalah pilihan corak pembangunan yang hendak kita tuju.

Kedua, sebagai realisasi dari pilihan strategis di atas, maka masyarakat pun didorong untuk mengikuti gaya hidup serba benda dan mengejar kekayaan sebanyak-banyaknya. Dari sini timbul sikap individualistis, dan melihat orang lain tidak lebih dari sekedar saingan. Hal ini akan memperhambar ikatan kebersamaan.

Ketiga, tuntutan hidup yang makin konsumeristis dan harus dipenuhi melalui persaingan keras akan menyulut konflik kepentingan. Dalam praksis kehidupan nyata sehari-hari kita saksikan, betapa keras persaingan untuk memperebutkan kucuran dari sekian banyak proyek pembangunan. Para pengusaha berebut untuk mendapatkan tender-tender yang ditawarkan, begitu pula rakyat berjubel antri memperoleh pelayanan dalam berurusan dengan birokrasi. Ternyata, dari sini muncul sogok-menyogok, suap-menyuap. Penyakit sosial ini makin berkembang dari waktu ke waktu.

Birokratisasi segala aspek kehidupan nyäris identik dengan penciptaan peluang untuk terjadinya perilaku tidak terpuji di atas. Jika dulu tindakan semacam ini hanya terjadi pada lingkungan birokrasi pemerintah tertentu dalam jumlah yang terbatas maka pada waktu lima tahun terakhir kecenderungan serupa juga telah melanda dunia swasta. Di dalam perusahaan-perusahaan swasta besar mulai terjadi sogok-menyogok dalam rekrutmen pegawai, bahkan gaya kerja serba proyek juga mulai berkembang di badan-badan swasta, sebagai sarana pembentukan peluang untuk memperoleh pendapatan tambahan di luar gaji resmi yang telah digariskan perusahaan. Mulai timbul broker-broker dalam rekrutmen pegawai baru, bahkan telah dikenal pula adanya jabatan-jabatan basah di perusahaan tersebut.

Keempat, munculnya gaya hidup konsumeristik berlebihan tịdak mungkin dielakkan dalam tatanan industri semacam ini. Inilah faktor pendorong pertumbuhan ekonomi dalam masyarakat kapitalis. Keserakahan dan keganasan untuk sebagian disulut oleh gaya hidup ini.

Kelima, teknologisasi kehidupan cenderung menimbulkan impersonalisasi. Frekuensi hubungan kemanusiaan makin menciut, sehingga proses keterasingan kian menggumpal. Manusia makin kikir dengan waktu, dan makin berkurang sikap kesetiakawanan sosial, karena dipersepsikan sebagai perbuatan sia-sia. John G. McGraw mencatat adanya sembilan jenis keterasingan atau kesenderian: metafisis, epistemologis, komunikatif, ontologis/impersonal, etis, eksistensial, emosional dan sosial, budaya dan kosmik. 
Keenam, ketimpangan dan ketidakadilan adalah sisi lain yang juga inheren dalam paradigma pembangunan yang terlalu berorientasi pertumbuhan. Di dalam kehidupan sehari-hari masyarakat kita makin terasa adanya jurang yang lebar antara yang kaya dan yang miskin. Mereka yang punya aksès langsung kepada birokrasi dan pusat-pusat ekonomi akan memperoleh perlakuan istimewa. Dari sini mereka mendapat peluang untuk memperkaya diri. Bagi birokrat ini berarti mereka menempati kedudukan "basah" yang akan dikucuri oleh banyak uang; sedangkan bagi pengusaha akan mendapatkan perlindungan. Kedudukan istimewa ini akhir-akhir ini cenderung menjadi salah satu sumber keresahan dan kebringasan sosial.

Sisi lain dari ketimpangan adalah pertumbuhan antara kawasan pedesaan dan perkotaan. Dari hari ke hari ketimpangan ini tidak mereda, bahkan cenderung bertambah parah. Kota menjadi pusat pemerintahan, pusat pendidikan, pusat industri, pusat hiburan, pusat perdagangan yang notabene adalah pusat peredaran uang. Ini penyulut utama urbanisasi dan atau migrasi.

Ketujuh, munculnya gaya hidup baru menuntut adanya adaptasi struktural-fungsional-simbolis. Di dalam masyarakat makin terasa adanya desakan gencar dari media massa menyuguhkan informasi yang memaksa masyarakat untuk masuk ke dalam lingkaran hidup konsumtif. Ini tampak dalam iklan-iklan yang tersaji maupun dalam wacana yang diperdebatkan para pakar dalam segala jenis media massa. Hal ini mengharuskan khalayak ramai untuk mengikuti pola hidup yang dikehendaki oleh para pemilik kapital dan mengharuskan mereka untuk melakukan adaptasi setelah dipakai melalui iklan-iklan tersebut. Dari sini sebenarnya kepribadian masyarakat digerogoti secara perlahan-lahan untuk menerima nilai kapitalistik. Dalam jangka panjang, identitas dan jatidiri bangsa pun bisa "tergadai", jika kecenderungan negatif ini tidak dibendung.

Pada aspek struktural jelas bahwa segenap institusi modern telah hadir dan bèrfungsi sebagai pengganti berbagai bentuk kelembagaan masyarakat. Forum-forum komunikasi di tingkat desa yang selama ini mumi milik rakyat dan bersifat non-formal nyaris hilang samasekali karena penetrasi birokrasi melalui berbagai kegiatan dan atas nama pembangunan. Birokrasi juga nyaris memonopoli segala wacana pembangunan melalui berbagai wadah yaing menjadi sarana perpanjangan tangannya.

Pada tingkat budaya dan simbolis pun penetrasi pranata modem pun sangat terasa dalam segala lapisan masyarakat, yang mengharuskan masyarakat menyesuaikan diri, jika tidak, ia akan terkucil atau dikucilkan orang.

Kedelapan, di dalam masyarakat, ketidakberdayaan menghadapi ekspansi pranata modem-birokratis juga ditandai oleh munculnya sikap pasrah berlebihan, berupa ketundukan yang memastikan kreativitas masyarakat. Hampir-hampir tidak ada dialog dan tawar-menawar. Lambat laun masyarakat juga akan bersikap apatis terhadap lingkungan di sekitamya, tidak ada lagi nyali untuk memperdebatkan, apalagi mempertanyakan segala keanehan yang terjadi dalam proses pembangunan. Ini merupakan satu gejala awal dari proses "pembusukan" yang akan dialami masyarakat. Sikap permissif ini dengan sendirinya akan menghilangkan daya kritis masyarakat, dan dari sini jangan diharap akan muncul manusia tangguh dengan kepribadian utuh. Sebagai akibat logisnya, tiak mungkin timbul satu kekuatan sosial yang akan melakukan kontrol terhadap segala program dan proses pembangunan. Hal ini sekaligus akan mempersubur iklim sentralisasi kekuasaan di tangan birokrasi, yang ujungnya akan bermuara pada konsolidasi kekuatan di tangan segelintir elite. Ini akan mempersulit pemberdayaan masyarakat yang idealnya akan bermuara pula kepada demokratisasi yang sehat dan dewasa. Dalam suasana demikian, jangan pula diharapkan akan lahimya partai politik yang berfungsi secara efektif sebagaimana layaknya di sebuah negara demokratis, karena semua kekuatan politik telah dibungkam dengan dalih menciptakan stabilitas, bahkan cenderung diseragamkan, tidak dibiasakan untuk bersikap mandiri, apalagi berbeda dengan keinginan para pemegang kekuasaan.

Begitu juga ormas makin hari makin kehilangan orientasi dan independensinya. Kekuatan masyarakat sudah "dipangkas", bahkan kelas menengah pun tidak memiliki kemandirian yang wajar dalam aktualisasi dirinya:

Kesembilan, keberagaman yang tidak fungsional. Disadari atau tidak, lahan gerak agama kian menyempit, tidak lebih dari sekedar aturan peribadatan formal dalam arti sempit. Ini merupakan konsekuensi logis dari proses transfer nilai-nilai dan ajaran agama melalui pewarisan dari para leluhur, dan bukan samasekali merupakan hasil pencarian sungguh-sungguh yang dihayati secara mendalam. Nilai-nilai etis Islam yang seharusnya menjadi penuntun tingkah laku tidak terefleksi dalam hidup keseharian. Misalnya, ajaran shalat yang menjanjikan dapat menangkal segala perbuatan tidak terpuji dan keji tidak menjadi kenyataan. Shalat lebih merupakan simbol identitas untuk dapat diakui dan mengidentifikasikan diri dalam komunitas muslim. Antara perilaku muslim yang rajin melakukan shalat dengan yang tidak samasekali nyaris tidak dapat 
dibedakan. Tingkah laku tercela yang terjadi di dalam pergaulan hidup sehari-hari juga dilakukan olch muslim yang mengerjakan shalat. Bahkan tidak pula sedikit pelaku korupsi yang kini mimenjadi penyakit sosial yang kronis di dalam masyarakat kita juga dilakukan olch anggota komunitas muslim. Hal ini menandakan bahwa keberagamaan yang diperoleh secara turun-menurun ternyata tidak disikapi dengan penuh kesadaran, sehingga agama tidak diletakkan dalam konteksnya yang benar.

Kesepuluh, munculnya sikap apatis berlcbihan dan hilangnya kebersamaan sosial dan kepekaan masyarakat, terutama di kota-kota besar, scbagai salah satu bentuk protes dari kehidupan yang terlalu mementingkan karir diri sendiri. Apalagi dengan penataan ruang pemukiman yang makin eksklusif mendorong timbulnya kesadaran kelas. Rakyat kecil makin tergusur ke pinggir karena didesak olch kepentingan pragmatis kaum kapitalis. Ini dapat menyulut kecemburuan sosial, bahkan kebringasan massal. Erat kaitannya dengan butir keenam di atas, makin hari makin langka kekuatan pengintegrasi masyarakat. Bahkan fragmentasi sosial menjadi bertambah parah; sedangkan mobilitas horisontal juga tidak mampu memperbaiki nasib rakyat kecil secara lebih berarti. Jika tidak ditemukan jalan pemecahan dari situasi yang tidak sehat ini, besar kemungkinan dapat muncul keresahan sosial di masa depan.

Kesebelas, fase transisi. Dalam ungkapan yang pendek, situasi yang menyelimuti masyarakat kita sekarang ini merupakan satu bentuk manifestasi dari masyarakat yang sedang memasuki fase transisi, yang ditandai oleh munculnya berbagai gejala aneh. Masyarakat kita kini dilanda olch sikap mendua, ambivalen, paradoksal. Konflik sering terjadi dalam tahap transisi tersebut. Bahkan konflik ini sendiri merupakan salah satu. prasyarat untuk mencapai kemajuan.

\section{Menghidupkan semangat agama}

Jika kita kaji secara seksama akan segera tampak bahwa sebenamya agama yang kita anut (Islam) diharapkan berfungsi sebagai penunjuk jalan ("hudan"), sebagai alat penginterpretasikan kenyataan ("tibyan"), dan sebagai landasan pembebas, transformatif ("rahmat"). Dengan demikian, idealnya di dalam komunitas yang mayoritas anggotanya memcluk Islam akan terpantul pula satu tatanan kchidupan yang mencerminkan etika Islam dalam segenap aspck kehidupan, sesuai dengan hakekat eksistensial Islam yang mengklaim diri untuk mengalur segala aspek kehidupan umat manusia.
Jika Islam menghendaki egalitarianisme dalam berekonomi dan berpolitik maka adalah tidak sewajamya jika praktis kehidupan ekonomi dan politik suatu negarabangsa yang berpenduduk mayoritas muslim justen terjadi ketimpangan distribusi akses kepada ekonomi dan ditandai pula dengan sistem pemerintahan despotis dan atau otoritarian.

Begitu juga ajaran etis Islam yang menghendaki adanya pemerintahan yang bersih dan bertanggungjawab tidak sewajarnya jika praktek penyelenggaraan kekuasaan dan pemerintahan bergelimangan dengan kolusi, korupsi dan berbagai bentuk penyalahgunaan kekuasaan lainnya. Sungguh tragis, jika negara berpenduduk terbesar keempat dunia dengan 88 persen beragama Islam justeru menempati posisi paling korup di dunia. Kita patut mempertanyakan, mengapa korupsi sistemik-endemik ini tidak dapat diatasi? Apakah ini bukan menupakan salah satu pencerminan dari kekelinuan persepsi keberagamaan masyarakat kita?

Menurut hemat penulis, perlu diadakan kajian mendalam tentang patologi sosial di atas, untuk dapat diketahui penyebab dan sekaligus langkah-langkah untuk menanggulanginya. Penanggulangan ini paling tidak memerlukan empat faktor: keinginan baik politik pemerintah untuk melakukan pemberantasan secara sungguh-sungguh, dukungan dari masyarakat, kepastian hukum, dan berfungsinya agama secara efektif dan maksimal.

Ajaran Islam jelas tidak mungkin berkompromi dengan korupsi. Allah telah menentukan garis yang tegas. Tetapi perintah agama ini makin hari makin dikaburkan orang. Berbagai aturan diciptakan untuk memberantas korupsi, tetapi korupsi tetap merajalela. Ada pengawasan melekat, namun korupsi tetap bergentayangan. Menurut hemat penulis, di dalam Islam sendiri ada juga bentuk pengawasan yang sesungguhnya, yaitu "waskal", pengawasan oleh malaikat. Muslim yang betul-betul taat beragama tidak mungkin melakukan tindakan "munkar" karena ia selalu diawasi oleh "Malaikat". Manusia bisa ditipu, disogok, diajak berkolusi, berkompromi di dalam kemunkaran, tetapi malaikat tidak mungkin dapat diajak ke arah tingkah laku anch. Inilah hakekat keberagamaan yang scsungguhnya, yakni mampu menyadarkan kepada pemcluknya, bahwa Allah telah menciptakan malaikat, dengan fungsi antara lain untuk mengawasi manusia, mencatat tingkah lakunya. Dari laporan malaikat inilah tingkah laku selunuh manusia dapat dihitung berapa yang positif, dan berapa pula yang negatif, untuk selanjutnya dipertanggungjawabkan di depan Allah melalui proses 
peradilan yang betul-betul adil dan jujur, untuk kemudian ditentukan tempatnya, di surga atau neraka. Tugas pemuka agama adalah menghidupkan semangat keberagamaan masyarakaț.

\section{Daftar Kepustakaan}

Andrain, Charles F. and David E. Apter, 1995, Political Protest and Social Change, New York: New York University Press.

Bell, Daniel. 1976. The Coming of Post-Industrial So- ciety. London: Heinemann.

Bellah, Robert N. 1970. Beyond Belief: Essay on Religion in Post-Traditional Societies. New York: Harper and Row, Publishers.

Mbiti, John S, 1971. African Religion and Philosophy. London: Heinemann.

McGraw, Jhon G. 1995. "Loneliness, its Nature and Forms: an Existensial Perspective" dalam Man and World, vol. 28 (1): 43-64.

Smart. Ninian. 1994. Religion of the West. Engelwood Cliffs, New Jersey: Prentice Hall. 